\title{
Spatial variation in soil active-layer geochemistry across hydrologic margins in polar desert ecosystems
}

\author{
J. E. Barrett ${ }^{1}$, M. N. Gooseff ${ }^{2}$, and C. Takacs-Vesbach ${ }^{3}$ \\ ${ }^{1}$ Department of Biological Sciences, Virginia Polytechnic Institute and State University, Blacksburg, VA 24061, USA \\ ${ }^{2}$ Department of Civil \& Environmental Engineering, Pennsylvania State University, University Park, PA 16802, USA \\ ${ }^{3}$ Department of Biology, University of New Mexico, Albuquerque, NM 87131, USA
}

Received: 25 February 2009 - Published in Hydrol. Earth Syst. Sci. Discuss.: 6 May 2009

Revised: 10 November 2009 - Accepted: 19 November 2009 - Published: 10 December 2009

\begin{abstract}
Polar deserts are characterized by severe spatialtemporal limitations of liquid water. In soil active layers of the Antarctic Dry Valleys, liquid water is infrequently available over most of the arid terrestrial landscape. However, soils on the margins of glacial melt-water streams and lakes are visibly wet during the brief Austral summer when temperatures permit the existence of liquid water. We examined the role of these hydrologic margins as preferential zones for the transformation and transport of nutrient elements and solutes in an environment where geochemical weathering and biological activity is strictly limited by the dearth of liquid water. We report on hydropedological investigations of aquatic-terrestrial transition zones adjacent to 11 stream and lake systems in the Antarctic Dry Valleys. Our results show that wetted zones extended 1-11 m from the edges of lotic and lentic systems. While capillary demand and surface evaporation drive a one-way flux of water through these zones, the scale of these transition zones is determined by the topography and physical characteristics of the surrounding soils. Nutrient concentrations and fluxes appear to be influenced by both the hydrology and microbialmediated biogeochemical processes. Salt concentrations are enriched near the distal boundary of the wetted fronts due to evapo-concentration of pore water in lake margin soils, while organic matter, ammonium and phosphate concentrations are highest in stream channel sediments where potential for biological activity is greatest. Thus, in the Antarctic Dry Valleys, intermittently wet soils on the margins of streams and lakes are important zones of both geochemical cycling and biological activity.
\end{abstract}

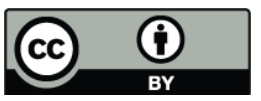

Correspondence to: J. E. Barrett (jebbare@ vt.edu)

\section{Introduction}

In temperate and alpine watersheds terrestrial-aquatic interfaces are critical zones of hydrologic and biogeochemical exchange, and create physical and chemical conditions that determine habitat suitability necessary to support high levels of biodiversity (Hedin et al., 1998; Sobczak et al., 1998; Carlyle and Hill, 2001; Findlay et al., 2001; Bargette et al., 2001; Hood et al., 2003). The emerging research focus of hydropedology seeks to understand how water flux and associated transport of chemicals and energy by flowing water across landscapes impact soil development, spatial variability, and ecosystem functioning (Lin et al., 2006). Arid environments may provide useful model systems for this nascent field for two reasons: 1 . The temporal and spatial variation in water availability and flow is a strong physical organizer of these systems, and 2. The limited role of biota in these systems provides opportunity to constrain interpretations of physical vs. biotic drivers. For example, in the McMurdo Dry Valleys of Antarctica and other cold desert ecosystems water is the primary limitation to geochemical weathering because its availability and movement is limited by low temperatures (Kennedy, 1993; Convey et al., 2003; Barrett et al., 2008). Moreover, the simple nature of these systems (e.g. no riparian vegetation, soils underlain by permafrost which constrains groundwater) lends itself to examinations of water movement and hydropedological processes in near-shore soils. In such environments aquatic-terrestrial transition zones are also essential habitats that support unusually productive and diverse biotic communities in an otherwise inhospitable environment (Treonis et al., 1999; Barrett et al., 2006; Ayres et al., 2007; Zeglin et al., 2009).

In the McMurdo Dry Valleys of Antarctica, these transition zones have been identified as critical linkages integrating the material and hydrologic budgets of the surrounding

Published by Copernicus Publications on behalf of the European Geosciences Union. 


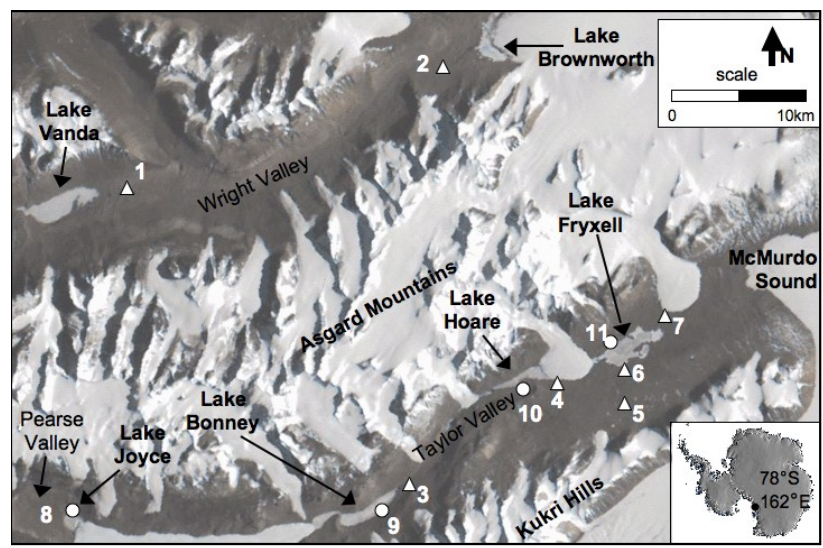

Fig. 1. Map of study sites in the McMurdo DryValleys, Antarctica: 1) Lower Onyx River; 2) Upper Onyx River; 3) Priscu Stream; 4) Green Creek; 5) Upper Delta Stream; 6) Lower Delta Stream; 7) Lost Seal Stream; 8) Lake Joyce; 9) Lake Bonney; 10) Lake Hoare; and 11) Lake Fryxell.

terrestrial and aquatic ecosystems (Lyons et al., 2000; Barrett et al., 2007). For example, riparian and lake-margin soils support relatively favorable microclimates (e.g. Cozetto et al., 2006; Ikard et al., 2009), which may facilitate nutrient transformations and transport between terrestrial and aquatic ecosystems (Barrett et al., 2002; Gooseff et al., 2004; Bate et al., 2008), in addition to being primary locations of geochemical weathering (Gooseff et al., 2002; Nezat et al., 2001). In this paper we report on examinations of active-layer geochemistry in the soils of lake margins and riparian zones of dry valley aquatic ecosystems. Our objective was to assess the spatial and temporal variability in soil biogeochemical and physical properties in hydrologic margins adjacent to stream and lakes in the McMurdo Dry Valleys. Such systems may provide insight to hydropedology and biogeochemical processes because of their relative simplicity in comparison to temperate systems where the influence of vascular plants and significant groundwater inputs obscure subsurface exchanges in aquatic-terrestrial transition zones.

\section{Methods}

\subsection{Site description}

The McMurdo Dry Valleys (Fig. 1) are a series of generally east to west oriented valleys located between the Ross Sea and the Polar Plateau in Southern Victoria Land, Antarctica. Mean daily air temperatures average $-17^{\circ} \mathrm{C}$, with winter minimum temperatures often below $-40^{\circ} \mathrm{C}$, summer maximums up to $10^{\circ} \mathrm{C}$ (Doran et al., 2002), and surface soil temperatures as high as $15^{\circ} \mathrm{C}$ (Barrett et al., 2008). Regionally, average annual temperatures range from $-18^{\circ} \mathrm{C}$ in coastal zones to $-24^{\circ} \mathrm{C}$ in high elevation soils of the dry valleys
(Aislabie et al., 2006). Annual precipitation inferred from limited observations and calculated from snow pits is less than $10 \mathrm{~cm}$ water equivalent, with sublimation losses dominating ablation rates, further limiting the availability of liquid water (Chinn, 1993; Witherow et al., 2006). Arid soils underlain by dry permafrost are the most extensive landform of the dry valleys occupying $61 \%$ of glacier ice-free surfaces below $1000 \mathrm{~m}$ elevation (Bockheim et al., 2007). Dry valley soils occurring in coastal areas and near contemporary lake edges are characterized by limited horizon development and shallow profiles with dry permafrost or ice cemented layers occurring generally within $30 \mathrm{~cm}$ of the surface (Campbell and Claridge, 1987; Bockheim, 2002).

Seasonal glacial melt is the primary source of liquid water to ephemeral streams and ice-covered lakes in the valleys (Bomblies et al., 2001). In contrast to the xeric conditions of upland terrestrial soils, wetted soils at the interface between aquatic and terrestrial landscapes are intermittently saturated through the short austral summers (Gooseff et al., 2007; Northcott et al., 2009) and support the most diverse and abundant soil food webs (Schwarz et al., 1993; Treonis et al., 1999; Barrett et al., 2006; Ayres et al., 2007). Liquid water is unavailable for most of the year, even in these near-shore environments because temperatures exceed $0^{\circ} \mathrm{C}$ for only brief periods (10-75 days) during the austral summer (Doran et at., 2002; Barrett et al., 2008).

Soils of the dry valleys have formed from a variety of parent materials, including sandstone, granite, diorite, dolerite and basalt, originating primarily in the exposed bedrock and glacial tills derived from several cycles of glaciation (Campbell and Claridge, 1987), and subsequently influenced by cycles of lake inundation and recession at low elevations (Lyons et al., 2000; Hall et al., 2001, 2002; Poreda et al., 2004). Soils are typically alkaline with broad ranges of salinity reflecting surface exposure age and local hydrological conditions (Bockheim, 1997; Northcott et al., 2009). Organic matter content of these soils is low, with a large proportion attributed to cyanobacterial mat material ablated from lake moats or redistributed lacustrine material from periods of high lake stands (Burkins et al., 2000; Elberling et al., 2006). Contemporary soil biological communities in the McMurdo Dry Valleys are characterized by low biomass, and are comprised of algae, cyanobacteria, bacteria, fungi, protozoans, and a very limited diversity of metazoan invertebrates (Adams et al., 2006; Aislabie et al., 2006; Connell et al., 2006).

\subsection{Study design and sampling}

In order to characterize the active layer geochemistry in hydrologic margins we present data collected from gradients of soil moisture adjacent to streams and lakes in the McMurdo Dry Valleys (Table 1). Sampling transects (4 replicates) were established perpendicular to dry valley streams and lakes extending from saturated lake or stream sediment into dry 
Table 1. Location and spatial dimensions of hydrological margins.

\begin{tabular}{|c|c|c|c|c|c|c|c|c|c|}
\hline Site & Valley & Latitude & Longitude & $\begin{array}{l}\text { Elevation } \\
\text { (m a.s.1.) }\end{array}$ & $\begin{array}{l}\text { Shore Slope } \\
(\mathrm{m} / \mathrm{m})^{*}\end{array}$ & $\begin{array}{l}\text { Mean Margin } \\
\text { Length }(\mathrm{m})^{*}\end{array}$ & $\begin{array}{l}\text { Mean Thaw } \\
\text { Depth }(\mathrm{m})^{*}\end{array}$ & $\begin{array}{l}\text { Bulk density } \\
(\mathrm{g} / \mathrm{ml})\end{array}$ & $\begin{array}{l}\text { Particle Size } \\
\text { Distribution** }\end{array}$ \\
\hline \multicolumn{10}{|l|}{ Stream Margins } \\
\hline Lower Onyx River & Wright & $77^{\circ} 31.412^{\prime}$ & $161^{\circ} 43.146^{\prime}$ & 145 & 0.24 & 1.22 & 0.35 & 1.70 & 84151 \\
\hline Upper Onyx River & Wright & $77^{\circ} 26.625^{\prime}$ & $162^{\circ} 39.587^{\prime}$ & 270 & 0.07 & 3.43 & 0.27 & 1.70 & 85141 \\
\hline Priscu Stream & Taylor & $77^{\circ} 41.653^{\prime}$ & $162^{\circ} 33.036^{\prime}$ & 65 & 0.07 & 5.69 & 0.26 & 1.67 & 73261 \\
\hline Green Creek & Taylor & $77^{\circ} 37.390^{\prime}$ & $163^{\circ} 3.925^{\prime}$ & 19 & 0.14 & 2.55 & 0.33 & 1.65 & 60382 \\
\hline Lower Delta Stream & Taylor & $77^{\circ} 37.498^{\prime}$ & $163^{\circ} 6.546^{\prime}$ & 24 & 0.05 & 7.65 & 0.43 & 1.68 & 75251 \\
\hline Upper Delta Stream & Taylor & $77^{\circ} 38.575^{\prime}$ & $163^{\circ} 7.918^{\prime}$ & 157 & 0.11 & 4.19 & 0.36 & 1.67 & 72271 \\
\hline Lost Seal Stream & Taylor & $77^{\circ} 35.404^{\prime}$ & $163^{\circ} 16.397^{\prime}$ & 32 & 0.09 & 4.49 & 0.23 & 1.63 & 51471 \\
\hline \multicolumn{10}{|l|}{ Lake Margins } \\
\hline Lake Joyce & Pearse & $77^{\circ} 42.989^{\prime}$ & $161^{\circ} 38.749^{\prime}$ & 301 & 0.13 & 2.93 & 0.37 & 1.60 & 35641 \\
\hline Lake Bonney & Taylor & $77^{\circ} 42.765^{\prime}$ & $162^{\circ} 28.385^{\prime}$ & 64 & 0.30 & 5.36 & 0.70 & 1.68 & 78202 \\
\hline Lake Hoare & Taylor & $77^{\circ} 37.931^{\prime}$ & $162^{\circ} 53.262^{\prime}$ & 73 & 0.19 & 2.35 & 0.30 & 1.65 & 59401 \\
\hline Lake Fryxell & Taylor & $77^{\circ} 36.424^{\prime}$ & $163^{\circ} 6.807^{\prime}$ & 18 & 0.07 & 11.04 & 0.28 & 1.64 & 54424 \\
\hline
\end{tabular}

* data from Northcott et al. (2009). ** particle size distribution for soils averaged across stream and lake margins; distributions are as follows: coarse sand and pebbles $(0.4-4 \mathrm{~mm})$, fine sand $(0.075-0.4 \mathrm{~mm})$ and soil material of less than $0.075 \mathrm{~mm}$ diameter.

soils. Transect lengths and sampling positions were determined individually for each moisture gradient based upon the observed distance of the distal boundary of saturated soils. These wetted fronts are visually conspicuous in the wellsorted soils surrounding dry valleys lakes, and usually for streams as well (Gooseff et al., 2007; Northcott et al., 2009). In cases where wetted fronts were not visually conspicuous a hand-held soil reflectometer (Delta T Devices) was used to determine the average distance from streams where soil pore water fell to below 5\% gravimetric water content. The theta probes were calibrated with known volumetric moisture contents of soils collected from the Lake Hoare site. Estimates of gravimetric soil moisture $(\% \mathrm{~g} / \mathrm{g})$ were calculated from the voltage output $(v)$ of the theta probes using the following equation:

$\varnothing=(1 / d)(-251 v 5+261 v 4-101 v 3+17 v 2-1.05 v)^{*} 100$

where $d$ is the bulk density of soils $(\mathrm{g} / \mathrm{ml})$ and $\emptyset$ is the gravimetric soil water content.

Transects included sampling positions located $0.2 \mathrm{~m}$ from open water in stream and lake margins (first position), and sampling positions $0.2 \mathrm{~m}$ from the wetted front on both the near-shore and uphill sides of this boundary (third and fourth positions, respectively); a sampling position was also located mid-way between open water and the edge of the wettedfront (second position). Salt deposits are typically visible within a few centimeters of the wetted fronts adjacent to stream and lake environments. Soils $(0-10 \mathrm{~cm}$ depth) were collected from these transects with hand-trowels in December 2004, December 2005 and January 2006 during periods of active stream flow and lake-moat melt out when open water conditions were present (Doran et al., 2008). Samples were also collected from pits excavated to $\sim 0.5 \mathrm{~m}$ from wetted zones adjacent to Lake Fryxell and Green Creek to characterize vertical distribution of solutes. Three pits were excavated in each location, two within the wetted zone and 1 from outside the wetted zone. Samples were stored at $4^{\circ} \mathrm{C}$ prior to processing and extractions for chemical composition.

\subsection{Analysis}

All soils were sieved and the $<2 \mathrm{~mm}$ fraction retained for analysis or physical and chemical properties. Basic physical and chemical properties of soils were determined on subsamples, and preliminary processing was performed in the Crary Laboratory at McMurdo Station, Antarctica. All subsequent analysis was preformed at the Dartmouth College Environmental Measurements Laboratory or the Virginia Tech Ecosystem Analysis Laboratory. Gravimetric water content was determined on soil subsamples that were oven-dried at $105^{\circ} \mathrm{C}$ for $48 \mathrm{~h}$. Soil ionic strength was estimated by measuring the electrical conductivity of a 1:5 solution of soil in DI water using a calibrated YSI conductivity meter. We measured soil $\mathrm{pH}$ on a 1:2 soil:DI water extract using an Orion $\mathrm{pH}$ meter.

Major ions were estimated from salt solution and deionized water extracts of soils using a 1:5 ratio of substrate to extractant. Soil extracts were shaken for $30 \mathrm{~min}$ on an orbital shaker and filtered through Whatman No. 42 filter paper and frozen prior to analyses. Major ion analytes were analyzed for $\mathrm{Cl}^{-}, \mathrm{NO}_{3}^{-}, \mathrm{SO}_{4}^{2-}, \mathrm{Ca}^{2+}, \mathrm{K}^{+}, \mathrm{Mg}^{2+}$, and $\mathrm{Na}^{+}$ using a Dionex ion chromatograph, and for major cations using a Spectra ICP-OES in the Dartmouth College Environmental Measurements Laboratory. Inorganic nutrient content of soils were determined on $2 \mathrm{M} \mathrm{KCl}$ and $0.5 \mathrm{M} \mathrm{NaHCO}_{3}$ extracts analyzed on a Lachat FIA Analyzer in the Crary Analytical Laboratory for ammonium, nitrate and phosphate concentrations (Keeney and Nelson, 1982; Olsen and Sommers, 
Table 2. ANOVA summaries (F ratios, probability values, and partial $r^{2}$ in parenthesis) of landscape (lotic vs. lentic) and transect position (distance from liquid water) affects on natural log transformed physical and chemical properties of dry valley soils in hydrological margins.

\begin{tabular}{|c|c|c|c|c|c|c|c|c|c|}
\hline & $\begin{array}{l}\ln (\text { water+1) } \\
(\% \mathrm{~g} / \mathrm{g})\end{array}$ & $\mathrm{pH}$ & $\begin{array}{l}\ln (\text { conductivity }+1) \\
(\mu \text { Siemens } / \mathrm{cm})\end{array}$ & $\ln \left(\mathrm{Cl}^{-}+1\right)$ & $\ln \left(\mathrm{SO}_{4}^{-2}+1\right)$ & $\begin{array}{r}\ln \left(\mathrm{Ca}^{2+}+1\right) \\
(\mathrm{mm}\end{array}$ & $\begin{array}{l}\ln \left(\mathrm{Mg}^{2+}+1\right) \\
1 / \mathrm{kg})\end{array}$ & $\ln \left(\mathrm{Na}^{+}+1\right)$ & $\ln \left(\mathrm{K}^{+}+1\right)$ \\
\hline Landscape type & $\begin{array}{l}5.20^{*} \\
(0.04)\end{array}$ & $\begin{array}{l}3.79 \\
(0.02)\end{array}$ & $\begin{array}{l}70.60^{* * * *} \\
(0.27)\end{array}$ & $\begin{array}{l}58.09^{* * * *} \\
(0.23)\end{array}$ & $\begin{array}{l}43.32^{* * * *} \\
(0.21)\end{array}$ & $\begin{array}{l}39.83^{* * * * *} \\
(0.18)\end{array}$ & $\begin{array}{l}34.52^{* * * * *} \\
(0.16)\end{array}$ & $\begin{array}{l}73.62^{* * * * *} \\
(0.28)\end{array}$ & $\begin{array}{l}40.60^{* * * *} \\
(0.19)\end{array}$ \\
\hline Transect position & $\begin{array}{l}278.60^{* * * * *} \\
(0.59)\end{array}$ & $\begin{array}{l}0.91 \\
(0.00)\end{array}$ & $\begin{array}{l}7.41^{* * * *} \\
(0.08)\end{array}$ & $\begin{array}{l}7.70^{* * * *} \\
(0.09)\end{array}$ & $\begin{array}{l}2.29 \\
(0.00)\end{array}$ & $\begin{array}{l}5.96^{* * *} \\
(0.08)\end{array}$ & $\begin{array}{l}3.84^{*} \\
(0.05)\end{array}$ & $\begin{array}{l}7.72^{* * * *} \\
(0.09)\end{array}$ & $\begin{array}{l}4.16^{* *} \\
(0.05)\end{array}$ \\
\hline Landscape* position & $\begin{array}{l}0.35 \\
(0.00)\end{array}$ & $\begin{array}{l}6.12^{* * *} \\
(0.10)\end{array}$ & $\begin{array}{l}1.53 \\
(0.00)\end{array}$ & $\begin{array}{l}3.83^{*} \\
(0.03)\end{array}$ & $\begin{array}{l}1.47 \\
(0.00)\end{array}$ & $\begin{array}{l}3.55^{*} \\
(0.04)\end{array}$ & $\begin{array}{l}2.39 \\
(0.00)\end{array}$ & $\begin{array}{l}3.15^{*} \\
(0.03)\end{array}$ & $\begin{array}{l}1.41 \\
(0.00)\end{array}$ \\
\hline
\end{tabular}

${ }^{*} P<0.05,{ }^{* *} P<0.01,{ }^{* * *} P<0.001,{ }^{* * * *} P<0.0001$

Table 3. ANOVA summaries (F statistic with $\mathrm{P}$ values, and partial $r^{2}$ in parenthesis) of landscape (lotic vs. lentic) and transect position (distance from liquid water) affects on nutrient and organic matter content of dry valley soils in hydrological margins.

\begin{tabular}{lllllll}
\hline & $\begin{array}{l}\ln \left(\mathrm{NH}_{4}^{+}+1\right) \\
(\mathrm{mg} \mathrm{N} / \mathrm{kg})\end{array}$ & $\begin{array}{l}\ln \left(\mathrm{NO}_{3}^{-}+1\right) \\
(\mathrm{mg} \mathrm{N} / \mathrm{kg})\end{array}$ & $\begin{array}{l}\ln \left(\mathrm{PO}_{4}^{3-}+1\right) \\
(\mathrm{mg} \mathrm{N} / \mathrm{kg})\end{array}$ & $\begin{array}{l}\ln (\mathrm{SOC}+1) \\
(\mathrm{g} \mathrm{C} / \mathrm{kg})\end{array}$ & $\begin{array}{l}\ln (\mathrm{TN}+1) \\
(\mathrm{g} \mathrm{N} / \mathrm{kg})\end{array}$ & $\mathrm{C}: \mathrm{N}$ \\
\hline Landscape type & $\begin{array}{l}14.66^{* * *} \\
(0.08)\end{array}$ & $\begin{array}{l}114.27^{* * * *} \\
(0.33)\end{array}$ & $\begin{array}{l}1.43 \\
(0.00)\end{array}$ & $\begin{array}{l}13.45^{* * * *} \\
(0.34)\end{array}$ & $\begin{array}{l}14.19^{* * * *} \\
(0.37)\end{array}$ & $\begin{array}{l}6.99^{* * * * *} \\
(0.028)\end{array}$ \\
\hline Transect position & 0.57 & $\begin{array}{l}17.05^{* * * *} \\
(0.15)\end{array}$ & $\begin{array}{l}2.62^{*} \\
(0.02)\end{array}$ & $\begin{array}{l}6.44^{* * *} \\
(0.05)\end{array}$ & $\begin{array}{l}4.74^{* *} \\
(0.04)\end{array}$ & $\begin{array}{l}1.60 \\
(0.00)\end{array}$ \\
\hline Landscape* position & $\begin{array}{l}2.75^{*} \\
(0.04)\end{array}$ & $\begin{array}{l}9.83^{* * * *} \\
(0.05)\end{array}$ & $\begin{array}{l}0.70 \\
(0.00)\end{array}$ & $\begin{array}{l}3.27^{* * * *} \\
(0.26)\end{array}$ & $\begin{array}{l}2.73^{* * * *} \\
(0.22)\end{array}$ & $\begin{array}{l}1.54 \\
(0.00)\end{array}$ \\
\hline
\end{tabular}

${ }^{*} P<0.05,{ }^{* *} P<0.01,{ }^{* * *} P<0.001,{ }^{* * * *} P<0.0001$

1982). Soil organic carbon and total nitrogen content of soils were determined from acidified sub-samples on CE Elantech Flash EA 1112 Elemental Analyzer (Lakewood, NJ) at the Virginia Tech Ecosystem Analysis Laboratory (Burkins et al., 2000). We use Analysis of variance (ANOVA) to partition variance in soil properties among spatial domains (moisture gradients, sites and landscape types) and over time (seasonal and annual). All statistical analyses were conducted in JMP $v$ 7.0. All data were $\log (x+1)$ transformed to satisfy the assumption of normal distribution when necessary.

\section{Result}

\subsection{Spatial variation in saturated soils}

Differences among study sites $(n=11)$ were a significant source of variation for all physical and geochemical properties examined (Tables 2 and 3). Since we were primarily interested in the influence of continuous moisture gradients on soil geochemistry, we focused our analysis on transect position effects (i.e. distance from lake or stream water). Water content of soils decreased as a function of horizontal distance from stream and lake shorelines in the dry valley lake and stream systems examined (Fig. 2a). For these extremely coarse soils (Table 1), saturation typically occurs at gravimetric water contents above 12-15\% (Jarvis and Messing, 1991). Soils were above saturation content in the 1st transect position $(20 \mathrm{~cm}$ from open water) and decreased to below $5 \%$ gravimetric soil water in samples collected from the 4th transect position most distant from stream and lake waters (Fig. 2a). Lake margin soils had higher water content on average than stream environments, though distance from liquid water accounted for most of the explainable variance across all the environments studied (Table 2). These results were consistent with visual observations of the wetted-front of saturated soils which extended up to the 3rd transect positions, 4-5 $\mathrm{m}$ on average, from open water (Fig. 2a).

Near-shore environments (within $20 \mathrm{~cm}$ of liquid water) had significantly higher $\mathrm{pH}$ in lake (9.0) vs. stream (8.3) soils, but were otherwise quite similar across dry valley stream and lake margins (Fig. 2b). Electrical conductivity (a proxy for ionic strength) of soil extracts varied significantly between lake and stream environments, and most notably across sampling transects (Fig. 2), with the 3rd transect positions (i.e. near the distal edge of the hydrologic margin) consistently exhibiting the highest electrical conductivity (Fig. 2c). These trends in electrical conductivity coincided with spatial variation in major ion concentrations. Major 

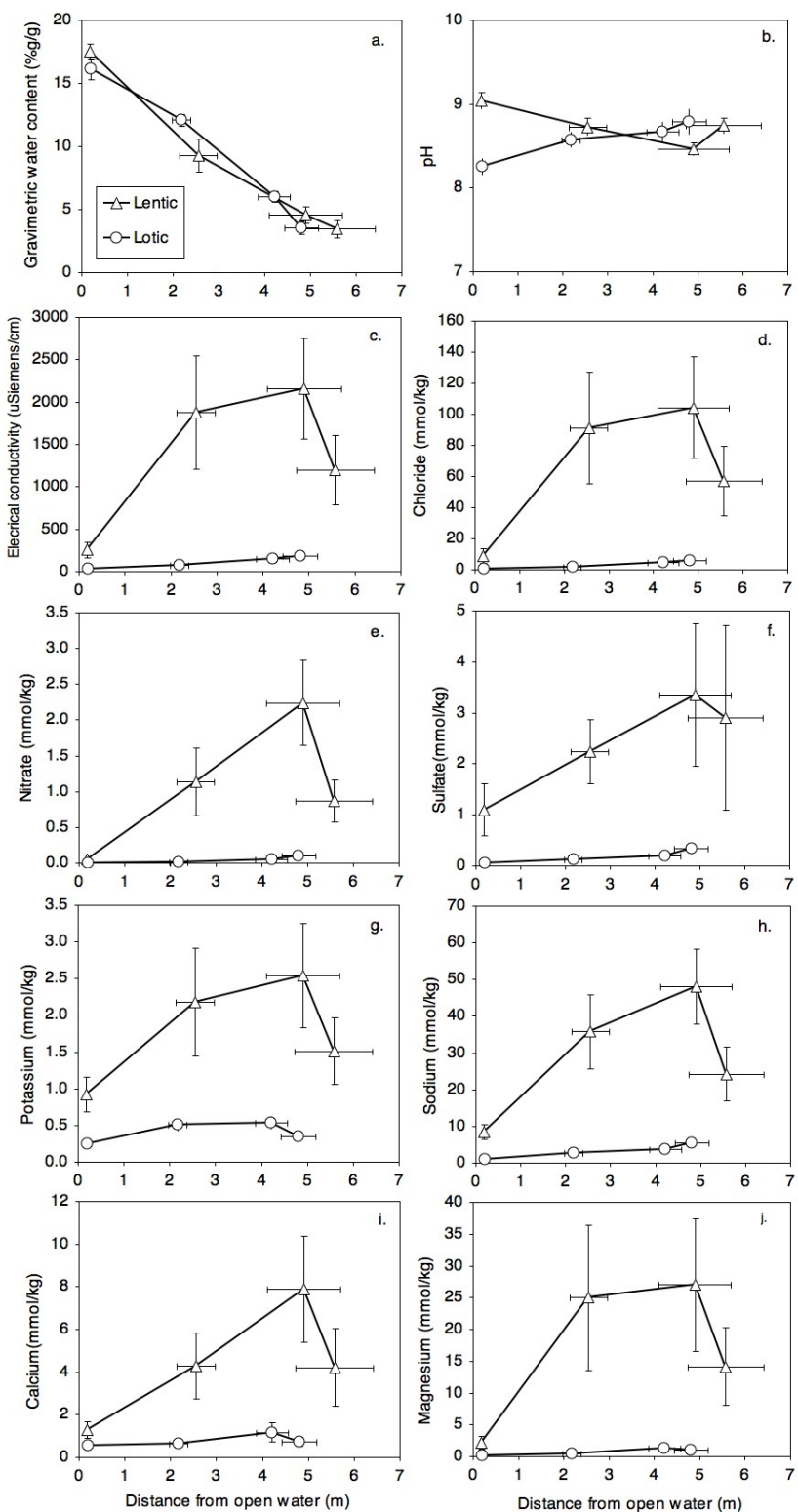

Fig. 2. Contemporary influences of stream and lake waters on nearshore water content and major ion concentrations in surface soils $(0-10 \mathrm{~cm})$ from 11 hydrologic margins of the McMurdo Dry Valleys (Fig. 1). Significance of landform (stream vs. lakes) and transect positions on soil properties are shown in Tables 2 and 3; error bars are standard error of the mean for $n=4$ and 7 pooled samples for lakes and streams, respectively.

ion $\left(\mathrm{Cl}^{-}, \mathrm{NO}_{3}^{-}, \mathrm{SO}_{4}^{2-}, \mathrm{K}^{+}, \mathrm{Na}^{+}, \mathrm{Ca}^{2+}, \mathrm{Mg}^{2+}\right)$ concentrations were greatest in the $3 \mathrm{rd}$ transect position near the distal boundary of the wetted fronts (Fig. 2d-j).

Lake margin soils had higher solute content relative to stream margin soils (Fig. 2). This effect was apparent in the overall model (Table 2) and strengthened when evaluated on a site by site basis; i.e. substituting individual study sites into statistical models in place of landscape type (i.e. stream vs. lake) markedly improved model fit for these variables (e.g. $R^{2}=0.95, P<0.0001$ for ANOVA of electrical conductivity by site). This effect illustrates the influence of till composition and surface exposure age on soil salt composition independent of hydrological effects (e.g. Bockheim, 1997; Barrett et al., 2007; Bate et al., 2008). Despite these regional gradients, solute content (anion and cation) was universally greatest in the soils collected from near the end of the moisture gradients across the sampling transects (Fig. 2) and all major ions were negatively correlated with water content except for ammonium and phosphate (Table 4).

Our estimates of nitrate concentration were similar for both the deionized water and $\mathrm{KCl}$ extraction techniques. Results from these analyses shared a high proportion of variance $\left(r^{2}=0.99\right)$, though nitrate concentrations measured on $\mathrm{KCl}$ extracts were $15 \%$ greater on average than nitrate extracted using deionized water. Here we report the results of $\mathrm{KCl}-$ extractions for estimates of nitrate based upon the assumption that $\mathrm{KCl}$ has greater extraction efficiency than deionized water.

Inorganic $\mathrm{N}$ concentration of soils varied across the sampling transects, with distinct trends evident for $\mathrm{NH}_{4}^{+}$and $\mathrm{NO}_{3}^{-}$. Nitrate concentrations were greatest at the distal boundary of the wetted front (Fig. 2e) in both lake and stream environments and exhibited a significant correlation with electrical conductivity of soil extracts $(r=0.32)$. Lake margins had significantly higher $\mathrm{NO}_{3}^{-}$concentrations relative to stream margin soils; a multiple regression model for $\mathrm{NO}_{3}^{-}$including landscape type (stream vs. lake) and conductivity accounted for $70 \%$ of the variation in $\mathrm{NO}_{3}^{-}$content of margin soils suggesting that controls over $\mathrm{NO}_{3}^{-}$transport are mainly physical. In contrast, $\mathrm{NH}_{4}^{+}$concentrations were higher in near-shore lake margin soils than in lotic environments (Fig. 3) and typically highest within a few meters of open water (Fig. 3a). Phosphate concentrations of soils exhibited similar spatial patterns to $\mathrm{NH}_{4}^{+}$content though differences between stream and lake margins were less pronounced (Fig. 3b).

Soil organic carbon and total $\mathrm{N}$ content was greatest in near shore lotic environments and decreased with increasing distance from open water (Table 3, Fig. 3c and d), exhibiting similar trends to soil water content with which these variables were strongly correlated (Table 4). Some inorganic nutrients followed similar patterns to carbon (Fig. 3). For example, $\mathrm{NH}_{4}^{+}$and $\mathrm{PO}_{4}^{3-}$ concentrations were correlated with soil water content and exhibited distinct spatial trends compared with other major ions $\left(\mathrm{Cl}^{-}, \mathrm{NO}_{3}^{-}, \mathrm{SO}_{4}^{2-}, \mathrm{K}^{+}, \mathrm{Na}^{+}\right.$, $\mathrm{Ca}^{2+}, \mathrm{Mg}^{2+}$ ), which appeared to be influenced primarily by physical conditions (i.e. wicking and evaporation) as well as by differences between streams and lake environments (Table 3).

Vertical variation in major ion concentration within the surface $0.5 \mathrm{~m}$ of soil profiles exhibited distinct patterns between lotic and lentic landscapes (Fig. 4). Nitrate, 
Table 4. Correlation matrix of log-transformed soil properties $(\mathrm{N}=157)$.

\begin{tabular}{|c|c|c|c|c|c|c|c|c|c|c|c|c|c|c|}
\hline & water & $\mathrm{pH}$ & E.C. & $\mathrm{NH}_{4}^{+}$ & $\mathrm{PO}_{4}^{3-}$ & $\mathrm{Cl}^{-}$ & $\mathrm{NO}_{3}^{-}$ & $\mathrm{SO}_{4}^{2-}$ & $\mathrm{Ca}^{2+}$ & $\mathrm{K}^{+}$ & $\mathrm{Mg}^{2+}$ & $\mathrm{Na}^{+}$ & $\mathrm{C}$ & $\mathrm{N}$ \\
\hline $\begin{array}{l}\text { Soil moisture content } \\
\text { (\% by weight) }\end{array}$ & 1.00 & & & & & & & & & & & & & \\
\hline $\mathrm{pH}$ & -0.14 & 1.00 & & & & & & & & & & & & \\
\hline $\begin{array}{l}\text { Electrical } \\
\text { conductivity }(\mu \mathrm{S} / \mathrm{cm})\end{array}$ & $-0.36^{* * *}$ & -0.05 & 1.00 & & & & & & & & & & & \\
\hline $\mathrm{NH}_{4}^{+}(\mathrm{mg} \mathrm{N} / \mathrm{kg})$ & -0.12 & 0.04 & $0.71^{* * *}$ & 1.00 & & & & & & & & & & \\
\hline $\mathrm{PO}_{4}^{3-}(\mathrm{mg} \mathrm{P} / \mathrm{kg})$ & $0.69^{* * *}$ & 0.34 & -0.10 & 0.10 & 1.00 & & & & & & & & & \\
\hline $\mathrm{Cl}^{-}(\mathrm{mmol} / \mathrm{kg})$ & $-0.35^{* * *}$ & -0.08 & 1.00 & 0.71 & -0.12 & 1.00 & & & & & & & & \\
\hline $\mathrm{NO}_{3}^{-}(\mathrm{mmol} / \mathrm{kg})$ & $-0.27^{* * *}$ & 0.02 & $0.32^{* * *}$ & 0.14 & 0.03 & $0.24 * *$ & 1.00 & & & & & & & \\
\hline $\mathrm{SO}_{4}^{2-}(\mathrm{mmol} / \mathrm{kg})$ & $-0.31^{* * *}$ & -0.02 & $0.87^{* * *}$ & $0.66^{* * *}$ & -0.10 & $0.86^{* * *}$ & $0.28^{* *}$ & 1.00 & & & & & & \\
\hline $\mathrm{Ca}^{2+}(\mathrm{mmol} / \mathrm{kg})$ & $-0.34^{* * *}$ & -0.11 & $0.94^{* * *}$ & $0.68^{* * *}$ & -0.14 & $0.95^{* * *}$ & $0.20^{*}$ & $0.91^{\text {**** }}$ & 1.00 & & & & & \\
\hline $\mathrm{K}^{+}(\mathrm{mmol} / \mathrm{kg})$ & $-0.31^{* * *}$ & 0.02 & $0.98^{* * *}$ & $0.75^{* * *}$ & -0.01 & $0.98^{* * *}$ & $0.27^{* *}$ & $0.88^{* * *}$ & $0.94^{* * *}$ & 1.00 & & & & \\
\hline $\mathrm{Mg}^{2+}(\mathrm{mmol} / \mathrm{kg})$ & $-0.32^{* * *}$ & -0.09 & $0.98^{* * *}$ & $0.70^{* * *}$ & -0.14 & $0.99^{* * *}$ & 0.13 & $0.82^{* * *}$ & $0.95^{* * *}$ & $0.96^{* * *}$ & 1.00 & & & \\
\hline $\mathrm{Na}^{+}(\mathrm{mmol} / \mathrm{kg})$ & $-0.37^{* * *}$ & 0.07 & $0.91^{* * *}$ & $0.64^{* * *}$ & 0.02 & $0.87^{* * *}$ & $0.62^{* * *}$ & $0.82^{* * *}$ & $0.82^{* * *}$ & $0.90^{* * *}$ & $0.81^{* * *}$ & 1.00 & & \\
\hline Soil organic $\mathrm{C}(\mathrm{g} / \mathrm{kg})$ & $0.32^{* * *}$ & 0.10 & -0.12 & $0.08^{*}$ & $0.66^{* * *}$ & -0.13 & 0.05 & $-0.16^{*}$ & -0.12 & -0.08 & $-0.15^{*}$ & -0.04 & 1.00 & \\
\hline Total soil N (g/kg) & $0.29^{* * *}$ & 0.09 & 0.00 & 0.14 & $0.70^{* * *}$ & -0.03 & $0.18^{*}$ & -0.05 & -0.02 & 0.04 & -0.05 & 0.12 & $0.97^{* * *}$ & 1.00 \\
\hline
\end{tabular}

${ }^{*} P<0.05,{ }^{* *} P<0.01,{ }^{* * *} P<0.001$
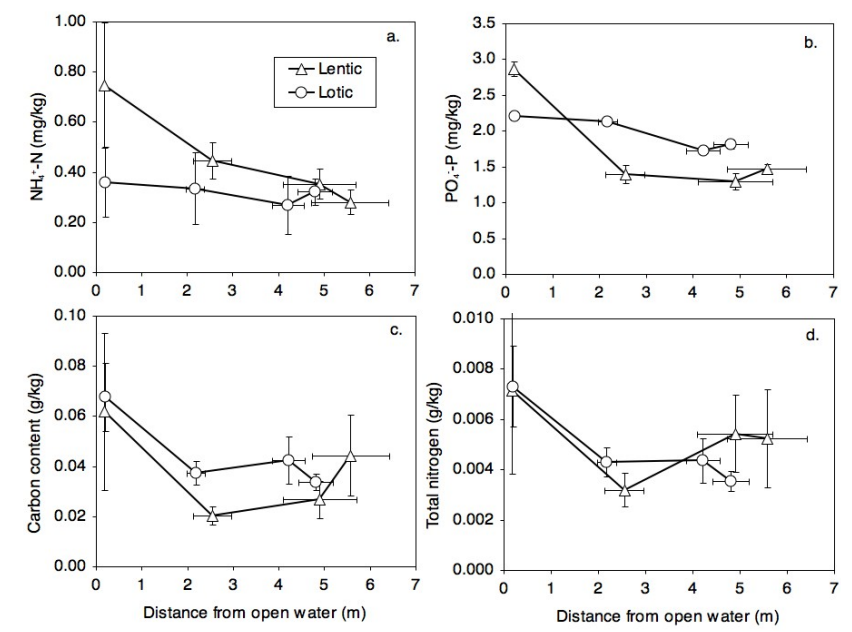

Fig. 3. Contemporary influences of stream and lake waters on nearshore soil nutrients in surface soils $(0-10 \mathrm{~cm})$ : (a) ammonium content, (b) phosphate content, (c) organic $\mathrm{C}$ content, (d) total $\mathrm{N}$ content. Error bars are standard error of the mean for $n=4$ and 7 pooled samples for lakes and streams, respectively.

ammonium and chloride concentrations were greatest in soils located within the wetted zone adjacent to Lake Fryxell (Fig. 4a-c). Nitrate and chloride concentrations were greatest within the top $10 \mathrm{~cm}$ of the surface; below $10 \mathrm{~cm}$ concentrations of nitrate and chloride were low and less variation was evident among the soil pits (Fig. $4 \mathrm{a}$ and c). Similar patterns were evident for soil organic C (Fig. 5) and total soil N (data not shown) for lake margin soils near Lake Fryxell with high concentrations of organic matter in surface soils; soil organic matter concentrations ( $\mathrm{C}$ and $\mathrm{N}$ ) were generally lower in soils collected from pits near Green Creek, but the low concentrations resulted in many samples being below detection limits and prevents statistical assessment of differences between stream and lake-side soil pits. Solute content of soils
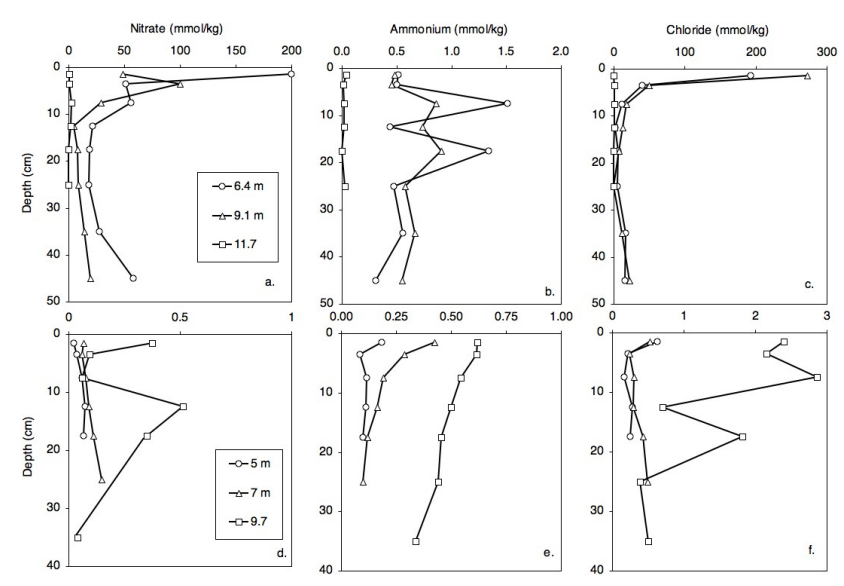

Fig. 4. Vertical profiles of subsurface chemical properties in soils adjacent to Lake Fryxell (a, b, c) and Green Creek (d, e, f). Distances of pits from shoreline are 6.4, 9.1 and $11.7 \mathrm{~m}$ from Lake Fryxell, and 5, 7 and $9.7 \mathrm{~m}$ from Green Creek.

from pits adjacent to Green Creek were more variable than those adjacent to Lake Fryxell and exhibited different trends with respect to the where maximum concentrations of solutes occurred. For example, the difference between surface and subsurface concentrations in stream-side nitrate and chloride concentrations was less pronounced than in lake margin soils. Moreover, higher concentrations of all solutes were evident in soils outside the wetted zone than in the soils adjacent to Green Creek (Fig. 4d-f).

\subsection{Temporal variation in saturated soils}

Dry valley lake and streams margins exhibited less seasonal and annual variation in geochemical properties of soils than spatial variation associated with moisture gradients. Seasonal variation (December 2005 vs. January 2006) was 
Table 5. ANOVA results for seasonal (December 2004 vs. January 2005) and annual (January 2005 vs. January 2006) time scales for soil biogeochemical variables.

\begin{tabular}{lll|ll}
\hline Variable & \multicolumn{2}{c}{ Seasonal } & \multicolumn{2}{c}{ Annual } \\
& F ratio & $R^{2}$ & F ratio & $R^{2}$ \\
\hline $\begin{array}{l}\text { Soil moisture } \\
\text { content }(\% \text { by wt })\end{array}$ & $3.75^{*}$ & 0.10 & 3.52 & 0.00 \\
$\mathrm{pH}$ & & & & \\
Electrical & 1.1 & 0.00 & 0.98 & 0.00 \\
conductivity $(\mu \mathrm{S} / \mathrm{cm})$ & 0.82 & 0.00 & 0.64 & 0.00 \\
$\mathrm{NH}_{4}^{+}(\mathrm{mg} \mathrm{N} / \mathrm{kg})$ & 1.45 & 0.00 & $10.85^{* *}$ & 0.03 \\
$\mathrm{NO}_{3}^{-}(\mathrm{mmol} / \mathrm{kg})$ & 1.11 & 0.00 & $102.66^{* * *}$ & 0.14 \\
$\mathrm{Cl}^{-}(\mathrm{mmol} / \mathrm{kg})$ & 0.56 & 0.00 & $3.83^{*}$ & 0.02 \\
\hline
\end{tabular}

${ }^{*} P<0.05,{ }^{* *} P<0.01,{ }^{* * *} P<0.001,{ }^{* * * *} P<0.0001$

significant only for water content, though it contributed to less than $1 \%$ of the variance across all lake and stream margins (Table 5). Inter-annual variability was noted only for inorganic $\mathrm{N}$ and chloride content of soils, though differences between January 2005 and January 2006 only contributed to small proportions of the variance in solute concentration (Table 5). In general, temporal variation was much less significant than the spatial variation detected across hydrological margins.

\section{Discussion}

This study demonstrates that hydropedological processes generate distinct geochemical patterns in near-shore stream and lake environments. In the McMurdo Dry Valleys, major landscape features such as glaciers, melt-water streams, lakes and soils are hydrologically linked over multiple time scales with the dynamics of local and regional hydrology driven predominantly by climatic variability (e.g. Lyons et al., 2000; Doran et al., 2008). The legacy of these paleoaquatic environments is preserved in contemporary patterns of soil geochemistry. Examination of contemporary spatial variation in surface geochemistry in hydrological margins points to mechanisms responsible for these prominent patterns in dry valley landscapes.

Biogeochemical properties of soils in aquatic terrestrial transition zones exhibited strong spatial patterns structured by the proximity and movement of liquid water. The most conspicuous influence of aquatic environments on neighboring soils is the wicking of water by capillary action into drier environments (Gooseff et al., 2007; Northcott et al., 2009). Water content varied significantly across aquatic-terrestrial transition zones adjacent to both streams and lakes in the McMurdo Dry Valleys (Fig. 2). These results are consistent with the visual observations of the wetted-front of saturated soils that extended 4-5 m from open water depending upon

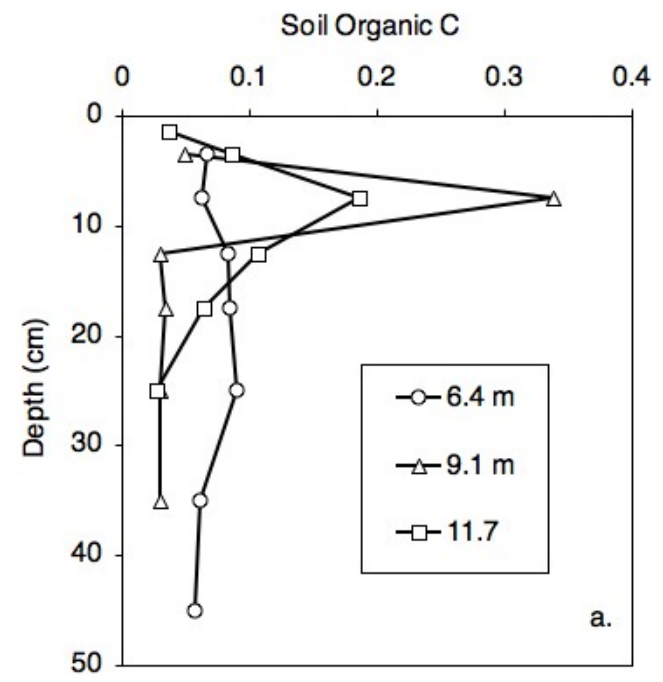

Fig. 5. Vertical profiles of organic carbon content in soils adjacent to Lake Fryxell; distances of pits from shoreline are given in Fig. 4.

topography and particle size distribution in soils (Gooseff et al., 2007). Differences in micro-topography associated with landscape heterogeneity, stream channel morphology and patterned ground adjacent to lakes (and often in the shallow sediments of lakes) may also play a role in water movement across hydrological margins; this could be an area of fruitful inquiry in future studies of hydropedology in polar deserts.

Spatial distribution of water in near shore soils has significant implication for terrestrial biological communities and biogeochemical cycling. For example, Treonis et al. (2000) suggested that the threshold for biological activity of Antarctic metazoan invertebrates is $4-5 \%$ soil water content by weight. Water content of soils outside the evaporative margins of streams and lakes were typically below 5\% water content by weight. Thus these hydrological margins may delineate zones of potential biological activity by multicellular organisms and trophic interactions in the McMurdo Dry Valleys. Together with organic matter and salinity, liquid water strongly limits the spatial distribution and activity of soil organisms (Treonis et al., 1999, 2000; Barrett et al., 2008; Poage et al., 2008; Zeglin et al., 2009).

The differences between spatial trends in inorganic nutrient concentrations illustrate important differences in source pools and resulting constraints on biological nutrient cycling in Antarctic environments. Atmospheric deposition is the dominant source of $\mathrm{NO}_{3}^{-}$in the McMurdo Dry Valleys (Campbell and Claridge, 1987; Michalski et al., 2005), whereas $\mathrm{NH}_{4}^{+}$may result from both physical (aerial deposition) and biological (decomposition of organic matter) processes (Barrett et al., 2002). Phosphorus availability in near-shore terrestrial environments and adjacent aquatic ecosystems is strongly influenced by geological substrate, 
and extent of chemical weathering processes (Barrett et al., 2007; Bate et al., 2008). Thus, the different spatial patterns evident for $\mathrm{NO}_{3}^{-}$relative to $\mathrm{NH}_{4}^{+}$and $\mathrm{PO}_{4}^{3-}$ in these stream and lake margins may illustrate a gradient in biological to physical control over nutrient cycling and mobility. In near shore saturated zones, elevated levels of $\mathrm{NH}_{4}^{+}$and $\mathrm{PO}_{4}^{3-}$ are associated with high organic matter and water content (Figs. 2 and 3) and greater biodiversity and biomass (Treonis et al., 1999; Barrett et al., 2006; Ayres et al., 2007). For example, total invertebrate abundance is typically greatest in the saturated soils on the periphery of streams and lakes, though variation in salinity among aquatic ecosystems also drives significant variance in soil communities (Treonis et al., 1999). Proximity to water sources facilitates higher microbial biomass, greater prevalence of invertebrates, and greater potential for biological activity in general (e.g. Zeglin et al., 2009), though this effect is most evident within one meter of open water (Takacs Vesbach et al., 2009); beyond that distance, physical processes associated with the wicking of water and evapo-concentration of salts appear to be the dominant geochemical processes.

The spatial patterns observed in water content, electrical conductivity and major ions are consistent with isotopic studies of near-shore environments which have shown that lake and stream margin pore waters generally exhibit an increasing enrichment of ${ }^{2} \mathrm{H}$ and ${ }^{18} \mathrm{O}$ with distance from the shore, and decreasing soil water content, suggesting evaporation of pore waters and concentration of solutes in these soils (Northcott et al., 2009). Our results show the evapoconcentration of solutes doesn't distinguish between cations and anions, probably reflecting the low exchange capacity of these low clay and organic matter soils. Only $\mathrm{NH}_{4}^{+}$and $\mathrm{PO}_{4}^{3-}$ were not concentrated in evaporative margins, perhaps reflecting their strong limitation and biotic demand in aquatic and near-shore environments (Barrett et al., 2007), alternatively this could be related to the low solubility of $\mathrm{PO}_{4}^{3-}$ at these high pHs and the high charge to mass ratio of ammonium. Together, these trends in physical and chemical properties and isotopic composition of pore waters support the conclusion that salts are accumulating at the distal boundary of the wetted fronts in dry valley lake and stream margins due to a combination of wicking of water due to capillary demand of the soils and evapo-concentration of dissolved solutes. This effect is most pronounced in soils adjacent to lakes where electrical conductivity and soil solute content are higher on average than in lotic environments (Table 2, Fig. 2) suggesting that this effect is largely driven by the more stable boundary of the wetted front that exists in lake margins compared with the evaporative margins in stream environments which are largely determined by temporal variation in flow (Conovitz et al., 1998).

The vertical variation in soil solute content we observed (Fig. 4) also supports this interpretation. For example, differences between surface and subsurface nitrate and chloride concentrations were most evident in pits excavated adjacent to lake margins where surface soils are subject to high evaporative fluxes. In contrast, differences between surface and subsurface concentrations of major ions were less pronounced in soils adjacent to Green Creek. Concentrations of major ions are several orders of magnitude lower in soils adjacent to Green Creek relative to lake margins (with the lowest overall values occurring in sediments closest to the stream), suggesting that these environments are flushed by the longitudinal movement of water associated with high steam flow. Hence, transport of major ions in stream margins are less influenced by evaporation than in lake margins.

These geochemical gradients evident at the distal boundary of wetted zones appear to be largely physically driven. Previous work has demonstrated significant spatial variation in invertebrate communities associated with the salinity gradients imposed by such conditions (Treonis et al., 1999; Ayres et al., 2007). Such patterns probably reflect allogenic drivers of community assembly. In contrast, the higher concentrations of organic matter and nutrients in saturated soils immediately adjacent to streams and lakes likely reflects contemporary and active biological processes by cyanobacterial mats. We hypothesize that these geochemical gradients also drive spatial patterns in subsurface microbial communities. The influence of microbial communities on potentially biogeochemically driven gradients is the subject of ongoing research. We hypothesize that such influence will be most evident within the intermittently saturated zones of aquaticterrestrial transitional environments.

\section{Summary}

Our results show that the dominant geochemical process in these Antarctic aquatic-terrestrial transition zones is transport of major ions across evaporative margins. Biological control over biogeochemical properties is evident in saturated soils, but diminishes with distance from the stream channel or lake edge. Thus, hydropedological properties and process are driven mainly by the physical structure of these transitional environments, with biotic transformations overlaying this physical template. These results are relevant to other environments where movement of water across soil and aquatic landscapes are dominated by fluxes limited to surface and shallow soil layers. In such systems hydropedological processes may be manifest in distinct spatial patterns of major ion chemistry and salinity gradients.

Acknowledgements. This work was funded by a National Science Foundation grant (\#0338174) and the McMurdo Dry Valleys Long Term Ecological Research program. Logistical support for field work was provided by Raytheon Polar Services and Petroleum Helicopters Inc. We are grateful to Brad Bate who processed the samples and to Paul Zietz, Robert VanTreese and Bobbie Niederliener who provided invaluable analytical support.

Edited by: H. Lin 


\section{References}

Adams, B. J., Bardgett, R. D., Ayres, E., Wall, D. H., Aislabie, J., Bamforth, S., Bargagli, R., Cary, C., Cavacini, P., Connell, L., Convey, P., Fell, J. W., Frati, F., Hogg, I. D., Newsham, K. K., O’Donnell, A., Russell, N., Seppelt, R. D., and Stevens, M. I.: Diversity and distribution of Victoria Land biota, Soil Biol. Bioch., 38, 3003-3018, 2006.

Aislabie, J. M., Chhour, K. L., Saul, D. J., Miyauchi, S., Ayton, J., Paetzold, R. F., and Balks, M. R.: Dominant bacteria in soils of Marble Point and Wright Valley, Victoria Land, Antarctica, Soil Biol. Bioch., 38, 3041-3056, 2006.

Ayers, E., Adams, B. J., Barrett, J. E., Virginia, R. A., Wall, D. H.: Soil and sediment biogeochemistry and faunal community structure across aquatic-terrestrial interfaces in a polar desert ecosystem, Ecosystems, 10, 523-535, 2007.

Bardgett, R. D., Anderson, J. M., Behan-Pelletier, V., Brussaard, L., Coleman, D. C., Ettema, C., Moldenke, A., Schimel, J. P., and Wall, D. H.: The influence of soil biodiversity on hydrological pathways and the transfer of materials between terrestrial and aquatic ecosystems, Ecosystems, 4, 421-429, 2001

Barrett, J. E., Virginia, R. A., and Wall, D. H.: Trends in resin and $\mathrm{KCl}$-extractable soil nitrogen across landscape gradients in Taylor Valley, Antarctica, Ecosystems, 5, 289-299, 2002.

Barrett, J. E., Virginia, R. A. Wall, D. H., Cary, S. C., Adams, B. J., Hacker A. L., and Aislabie, J. M.: Co-variation in soil biodiversity and biogeochemistry in northern and southern Victoria Land, Antarctica. Antarct. Sci., 18, 535-548, 2006.

Barrett, J. E., Virginia, R. A., Lyons, W. B., McKnight, D. M., Priscu, J. C., Doran, P. T., Fountain, A. G., Wall, D. H., and Moorhead D. L.: Biogeochemical stoichiometry of Antarctic Dry Valley ecosystems, J. Geophys. Res., 112, G01010, doi:10.1029/2005JG000141, 2007.

Barrett, J. E., Virginia, R. A., Wall, D. H., Doran, P. T., Fountain, A. G., Welch K. A., and Lyons, W. B.: Persistent effects of a discrete climate event on a polar desert ecosystem, Glob. Change. Biol., 14, 2249-2261, 2008.

Bate, D. B., Barrett, J. E., Poage M. A., and Virginia R. A.: Soil phosphorus cycling in an Antarctic Polar Desert, Geoderma, 144, 21-31, 2008.

Bockheim, J. G.: Properties and classification of cold desert soils from Antarctica, Soil Sci. Soc. Am. J., 61, 224-231, 1997.

Bockheim, J. G.: Landform and soil development in the McMurdo Dry valleys, Antarctica, a regional synthesis, Arct. Antarct. Alp. Res., 34, 308-317, 2002.

Bomblies, A., McKnight, D. M., and Andrews, E. D.: Retrospective simulation of lake-level rise in Lake Bonney based on recent 21year record, indication of recent climate change in the McMurdo Dry Valleys, Antarctica, J. Paleolimn., 25, 477-492, 2001.

Burkins, M. B., Virginia, R. A., Chamberlain, C. P., and Wall, D. H.: Origin and distribution of soil organic matter in Taylor Valley, Antarctica, Ecology, 81, 2377-2391, 2000.

Campbell, I. B. and Claridge, G. G. C.: Antarctica, Soils, Weathering Processes and Environment, Developments in Soil Science 16, Elsevier Press, Amsterdam, 1987.

Carlye, G. C. and Hill, A. R.: Groundwater phosphate dynamics in a river riparian zone: effects of hydrologic flowpaths, lithology and redox chemistry, J. Hydrol., 247, 151-168, 2001.
Chinn, T. H.: Physical hydrology of the dry valley lakes, in: Physical and Biogeochemical Processes in Antarctic Lakes, Antarctic Research Series, edited by: Green, W. J. and Friedmann, E. I., American Geophysical Union, Washington, D.C., 59, 1-51, 1988.

Connell, L., Redman, R., Craig, S., and Rodriguez, R.: Distribution and abundance of fungi in the soils of Taylor Valley, Antarctica, Soil Biol. Biochem., 38, 3083-3094, 2006.

Conovitz, P. A., Mcknight, D. M., Macdonald, L. H., Fountain, A. G., and House, H. R.: Hydrological processes influencing streamflow variation in Fryxell Basin, Antarctica, in: Ecosystem Dynamics in a Polar Desert: The McMurdo Dry Valleys, Antarctica, Antarctic Research Series, edited by: Priscu, J. C., American Geophysical Union, 93-108, 1998.

Convey, P., Block W., and Peat, H. J.: Soil arthropods as indicators of water stress in Antarctic terrestrial habitats, Glob. Change Biol., 9, 1718-1730, 2003.

Cozzetto, K., McKnight, D., Nylen, T., and Fountain, A.: Experimental investigations into processes controlling stream and hyporheic temperatures, Fryxell Basin, Antarctica, Adv. Water Resour., 29, 130-153, 2006.

Doran, P. T., McKay, C. P., Clow, G. D., Dana, G. L., Fountain, A. G., Nylen, T., and Lyons, W. B.: Valley floor climate observations from the McMurdo dry valleys, Antarctica 1986-2000, J. Geophys. Res. Atmos., 107, 4772, doi:10.1029/2001JD002045, 2002.

Doran, P. T., McKay, C. P., Fountain, A. G., Nylen, T., McKnight, D. M., Jaros, C., and Barrett, J. E.: Hydrologic response to extreme warm and cold summers in the McMurdo Dry Valleys, East Antarctica, Antarc. Sci., 20, 499-509, 2008.

Elberling, B., Gregorich, E. G., Hopkins, D. W., Sparrow, A. D., Novis, P., and Greenfield, L. G.: Distribution and dynamics of soil organic matter in an Antarctic dry valley, Soil. Biol. Biochem., 38, 3095-3106, 2006.

Findlay, S., Quinn, J. M., Hickey, C. W., Burrell, G., and Downes, M.: Effects of land use and riparian flowpath on delivery of dissolved organic carbon to streams, Limn. Oceanogr., 46, 345-355, 2001.

Gooseff, M. N., McKnight, D. M., Lyons, W. B, and Blum, A. E.: Weathering reactions and hyporheic exchange controls on stream water chemistry in a glacial meltwater stream in the McMurdo Dry Valleys, Water Resour. Res., 38, 1279, doi:1210.1029/2001WR000834, 2002.

Gooseff, M. N., Northcott, N. L., Barrett, J. E., Bate, D. B., Hill, K., Zeglin, L. H., Bobb, M., and Vesbach, C. D.: Controls on soil water dynamics in near-shore lake environments in an Antarctic polar desert, Vadose Zone J., 6, 841-848, 2007.

Hall, B. L., Denton, G. H., and Overturf, B.: Glacial Lake Wright, a high-level Antarctic lake during the LGM and early Holocene, Antarc. Sci., 13, 53-60, 2001.

Hall, B. L., Denton, G. H., Overturf, B., and Hendy, C. H.: Glacial Lake Victoria, a high-level Antarctic lake inferred from lacustrine deposits in Victoria Valley, J. Quater. Sci., 17, 697-706, 2002.

Hedin, L. O., von Fischer, J. C., Ostrom, N. E., Kennedy, B. P., Brown, M. G., and Robertson, G. P.: Thermodynamic constraints on nitrogen transformations and other biogeochemical processes at soil-stream interfaces, Ecology, 79, 684-703, 1998. 
Hood, E., Williams, M. W., and Caine, N: Landscape controls on organic and inorganic nitrogen leaching across an alpine-subalpine ecotone, Green Lakes Valley, Colorado Front Range, Ecosystems, 6, 31-45, 2003.

Ikard, S. J., Gooseff, M. N., Barrett, J. E., and Takacs-Vesbach C. D.: Active Layer Thermal Characterization Across a Soil Moisture Gradient In the McMurdo Dry Valleys, Antarctica, Permafrost Periglac, 20, 27-39, 2009.

Jarvis, N. J. and Messing I.: Near-saturated hydraulic conductivity in soils of contrasting texture measured by tension infiltrometers, Soil Sci. Soc. Am. J., 59, 27-34, 1995.

Keeney, D. R. and Nelson, D. W.: Nitrogen - Inorganic forms, in: Methods of soil analysis. Chemical and microbiological properties, edited by: Page, A. L., Agronomy, Am. Soc. of Agron., Madison, WI, 9(2), 643-698, 1982.

Kennedy, A. D.: Water as a Limiting Factor in the Antarctic Terrestrial Environment - a Biogeographical Synthesis, Arct. Alp. Res., 25, 308-315, 1993.

Lyons, W. B., Fountain, A. G., Doran, P. T., Priscu, J. C., Neumann, K., and Welch, K. A.: Importance of landscape position and legacy, the evolution of the lakes ion Taylor Valley, Antarctica, Freshwater Biol., 43, 355-367, 2000.

Lin, H. S., Bouma, J., Pachepsky, Y., Western, A., Thompson, J., van Genuchten, M. Th., Vogel, H., and Lilly. A.: Hydropedology: Synergistic integration of pedology and hydrology, Water Resour. Res., 42, W05301, doi:10.1029/2005WR004085, 2006.

Michalski, G., Bockheim, J. G., Kendall, C., and Thiemens, M.: Isotopic composition of Antarctic Dry Valley nitrate, Implication for NOy sources and cycling in Antarctica, Geophys. Res. Let., 32, L13817, doi:10.1029/2004GL022121, 2005.

Nezat, C. A., Lyons, W. B., and Welch, K. A.: Chemical weathering in streams of a polar desert (Taylor Valley, Antarctica), GSA Bull., 113, 1401-1408, 2001.

Northcott, M. L., Gooseff, M. N., Barrett, J. E., Zeglin, L. H., Takacs-Vesbach, C. D., and Humphrey, J.: Hydrologic characteristics of lake- and stream-side riparian margins in the McMurdo Dry Valleys, Antarctica, Hydrol. Process., 23, 1255-1267, 2009.

Olsen, S. R. and Sommers, L. E.: Phosphorus, in:Methods of soil analysis, Chemical and microbiological properties, edited by: Page, A. L., Agronomy, Am. Soc. of Agron., Madison, Wis., 9(2), 403-430, 1982.
Poage, M. A., Barrett, J. E., Virginia, R. A., and Wall, D. H.: The influence of soil geochemistry on nematode distribution, McMurdo Dry Valleys, Antarctica, Arct. Antarct. Alp. Res., 40, 119-128, 2008.

Poreda, R. J., Hunt, A. G., Lyons, W. B., and Welch, K. A.: The helium isotopic chemistry of Lake Bonney, Taylor Valley, Antarctica, Timing of Late Holocene climate change in Antarctica, Aquat. Geochem., 10, 353-371, 2004.

Schwarz, A. M. J., Green, J. D., Green, T. G. A., and Seppelt, R. D.: Invertebrates associated with moss communities at Canada Glacier, southern Victoria Land, Antarctica, Polar Biol., 13, 157$162,1993$.

Sobczak, W. V., Hedin, L. O., and Klug M. J.: Relationships between bacterial productivity and organic carbon at a soil-stream interface, Hydrobiol., 386, 45-53, 1998.

Takacs-Vesbach, C., Zeglin, L., Barrett, J. E., Gooseff, M. N., and Priscu, J. C.: Factors promoting microbial diversity in the McMurdo Dry Valleys, in: Life in Antarctic deserts and other cold and dry environments: Astrobiological analogues, edited by: Doran, P., Lyons, W. B., and McKnight, D. M., Cambridge University Press, Astrobiology Series, in press, 2009.

Treonis, A. M., Wall, D. H., and Virginia, R. A.: Invertebrate biodiversity in Antarctic dry valley soils and sediments, Ecosystems, 2, 482-492, 1999.

Treonis, A. M., Wall, D. H., and Virginia, R. A.: The use of anhydrobiosis by soil nematodes in the Antarctic Dry Valleys, Funct. Ecol., 14, 460-467, 2000.

Witherow, R. A., Lyons, W. B., Bertler, N. A. N., Welch, K. A., Mayewski, P. A., Sneed, S. B., Nylen, T., Handley, M. J., and Fountain, A.: The aeolian flux of calcium, chloride and nitrate to the McMurdo Dry Valleys landscape, evidence from snow pit analysis, Antarct. Sci., 18, 497-505, 2006.

Zeglin, L. H., Sinsabaugh, R. L. Barrett, J. E., Gooseff, M. N., and Takacs-Vesbach, C. D: Landscape distribution of microbial activity in the McMurdo Dry Valleys: Linked biotic processes, hydrology and geochemistry in a cold desert ecosystem, Ecosystems, 12, 562-573, 2009. 